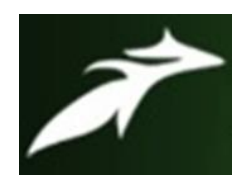

ARAVIND V. RAMA DAS et al, International Journal of Advances in Agricultural Science and Technology,

Vol.8 Issue.7, July-2021, pg. 116-122

ISSN: 2348-1358

Impact Factor: 6.057

NAAS Rating: 3.77

\title{
FACTORS INFLUENCING TRIBAL FARMERS TO SHIFT FROM TRADITIONAL TO MODERN AGRICULTURE IN WAYANAD DISTRICT OF KERALA
}

\author{
ARAVIND V. RAMA DAS ${ }^{1}$; DIPAK KUMAR BOSE ${ }^{2}$; JAHANARA ${ }^{3}$ \\ ${ }^{1}$ Research Scholar, Department of Agriculture Extension and Communication, SHUATS, Allahabad, \\ Uttar Pradesh, India \\ ${ }^{2}$ Associate Professor, Department of Agriculture Extension and Communication, SHUATS, \\ Allahabad, Uttar Pradesh, India \\ ${ }^{3}$ Professor and Head, Department of Agriculture Extension and Communication, SHUATS, \\ Allahabad, Uttar Pradesh, India
}

DOI: 10.47856/ijaast.2021.v08i7.013

\begin{abstract}
Agriculture has always been a way of life and culture for the traditional farmers. The major occupation of the tribal communities has always been agriculture. The pressure to meet the growing demands of the increasing population forced countries like India to adopt modern methods of farming. This gradually brought about changes in the ancient farming systems that existed in the Country. Kurichiya tribal community in Wayanad district of Kerala is the first agricultural community in the district and has an important role in the agricultural sector of the State. Today, changes have taken place in various aspects of the farming they follow, as a result of influence fro0m several factors. The study was conducted in Wayanad district of Kerala purposively for analyzing the socio-economic profile and the association of selected independent variables with factors influencing the Kurichiya tribal farmers to shift from traditional to modern agricultural system. The study was conducted using Descriptive research design. A total of 120 respondents were selected for the study. Pre-tested schedule was used for collection of data and statistical tools were used for analyzing. Karl Pearsons's Co-efficient of Correlation test was used to find the association between independent variables and factors influencing the respondents. The important findings of the study were that the factors influencing had a highly significant and positive relationship with Education, Mass Media exposure and Progressiveness.
\end{abstract}

\section{INTRODUCTION:}

Agriculture is a miscellaneous and extensive sector involving a large number of actors (Borthakur and Singh, 2012). Wayanad is a biodiversity rich district in the State of Kerala and is having a larger tribal population (Vaisakh and Sood, 2017). The topography of the district is responsible for a unique climate in the district (Kumar and Srinath, 2011). The tribal farmers practice traditional agricultural methods and the traditional knowledge is passing from one generation to another through word of mouth. The tribal farmers of Kurichya tribal community in Wayanad district have been making important contributions to the agriculture sector of the State (Jalaja and Kala, 2015). They were the first to start farming, having settled in Wayanad (Syam, 2016). They hold a vast knowledge of the traditional cultivation systems, which they earned from their ancestors and developed through experience and close interaction with the nature. Shifting cultivation or Slash and Burn cultivation was the common farming practice adopted by most of the tribes during the earlier period (Chacko, 2017). Restrictions imposed on slash and burn cultivation by the British colonial rule forced them to restrict the cultivation of diverse millets, which was the staple food of the tribes. The introduction of plantation crops like 


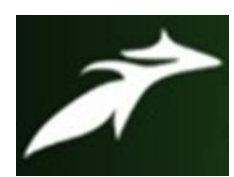

ARAVIND V. RAMA DAS et al, International Journal of Advances in Agricultural Science and Technology, Vol.8 Issue.7, July-2021, pg. 116-122

ISSN: 2348-1358

Impact Factor: 6.057

NAAS Rating: 3.77

Coffee, Tea, Cardamom, etc. during the British period further deteriorated the prospects of cultivating staple millets. Instead of hill slopes, the tribal farmers started to use valleys for the production of rice and millets, and thereby made their entry into settled agriculture. They developed and practiced various cultivation methods by understanding the natural balance in the environment and followed the principle of allowing nature to provide them the food in the way nature intended to do it. They followed joint family system and joint farming system (Sanal and Atheeque, 2018).

Mass migration of people from Travancore region to Wayanad, influenced by the cultivation of plantation crops, brought in lots of changes in agriculture, as they adopted relatively new practices and crops that were prevailing in the planes of Travancore region. The settlers were also keen to follow modern practices that came up with green revolution, while the tribal farmers were initially hesitated to move away from the traditional system they had been following for generations. But gradually, due to the influence of several factors, modernisation affected the traditional agricultural system followed by the tribal communities. The product of adaptation of farming practices to the local environment is the Indigenous agricultural knowledge (David et al, 2012). Presently, the influences of modern agricultural practices are seen reflected on the traditional methods followed by the tribal farmers. Changes have taken place in different aspects of farming they have been following since years.

Keeping these points in view, the present study was conducted with the following objectives:

- To determine the socio-economic profile of the respondents.

- To find out the association between independent variables and factors influencing tribal farmers to shift from traditional to modern farming system.

\section{Research Methodology:}

This part explains the methods that were applied for data collection and analysis. The present study was conducted using descriptive research design. It is used to describe the characteristics of a population or a phenomenon being studied. Descriptive research can be defined as a scientific method which involves observing and describing the behaviour of the subject, without influencing it in anyway. Wayanad district of Kerala was selected purposively for the study as the district is having maximum number of tribal population in the state. Out of the 3 blocks of Wayanad district, Mananthavady block has been selected purposively for the present study as the block is having maximum population of Kurichiya tribal farmers. A list of all the villages in the block was made and 5 villages were selected from them based on having maximum number of Kurichiya farmers. A total of 120 members were selected, 12 each from 10 hamlets, with the help of promoters and agriculture supervisor of respective village (VLW), based on the farmers experience in agriculture. The primary data was collected following personal interview technique with the help of an interview schedule designed based on specific objectives focused study. Secondary data was collected from books, journals, library, papers and other relevant sources related to the study. The quantitative data collected through survey was analysed using descriptive statistical tools. The raw data was coded and stored using Microsoft Excel spreadsheet in order to avoid anonymity of the respondents. The qualitative data was tallied and prioritized in order to determine trends and patterns in the data and make conclusions. 


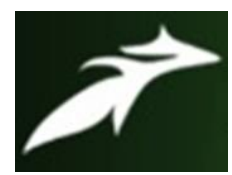

ARAVIND V. RAMA DAS et al, International Journal of Advances in Agricultural Science and Technology,

Vol.8 Issue.7, July-2021, pg. 116-122

ISSN: 2348-1358

Impact Factor: 6.057

NAAS Rating: 3.77

\section{RESULTS AND DISCUSSIONS}

Table-1: Socio-economic profile of the respondents

\begin{tabular}{|c|c|c|c|c|}
\hline Sl.no. & Socio-economic prot & le of the respondents & Frequency & Percentage \\
\hline \multirow[t]{3}{*}{1.} & \multirow[t]{3}{*}{ Age } & Low (20-35 years) & 18 & 15.00 \\
\hline & & Medium(36-50 years) & 55 & 45.84 \\
\hline & & $\operatorname{High}(>50$ years $)$ & 47 & 39.16 \\
\hline \multirow[t]{5}{*}{2.} & \multirow[t]{5}{*}{ Education } & Illiterate & 30 & 25.00 \\
\hline & & Primary & 56 & 46.66 \\
\hline & & Upper primary & 14 & 11.66 \\
\hline & & Secondary & 15 & 12.50 \\
\hline & & Higher secondary & 5 & 4.18 \\
\hline \multirow[t]{3}{*}{3.} & \multirow[t]{3}{*}{ Annual income } & Low (up to Rs.48000) & 82 & 68.33 \\
\hline & & Medium (Rs.48000-96000) & 30 & 25.00 \\
\hline & & High (>Rs.96000) & 8 & 6.66 \\
\hline \multirow[t]{2}{*}{4.} & \multirow[t]{2}{*}{ Family type } & Nuclear family & 109 & 90.83 \\
\hline & & Joint family & 11 & 9.16 \\
\hline \multirow[t]{3}{*}{5.} & \multirow[t]{3}{*}{ Mass Media Exposure } & Low & 42 & 35.00 \\
\hline & & Medium & 34 & 28.33 \\
\hline & & High & 44 & 36.66 \\
\hline \multirow[t]{3}{*}{6.} & \multirow[t]{3}{*}{ Extension contact } & Low & 37 & 30.83 \\
\hline & & Medium & 71 & 59.16 \\
\hline & & High & 12 & 10.00 \\
\hline \multirow[t]{3}{*}{7.} & \multirow[t]{3}{*}{ Progressiveness } & Low & 6 & 5.00 \\
\hline & & Medium & 17 & 14.16 \\
\hline & & High & 97 & 80.83 \\
\hline \multirow[t]{3}{*}{8.} & \multirow[t]{3}{*}{ Scientific orientation } & Low & 11 & 9.16 \\
\hline & & Medium & 32 & 26.66 \\
\hline & & High & 77 & 64.16 \\
\hline
\end{tabular}

From table-1. The results are depicted as follows.

A majority of the respondents, 45.84 per cent, belong to middle aged group (36-50 years), which is followed by 39.16 per cent of the respondents in old aged group (above 50), and a small percentage of 15.00 belongs to young age.

In terms of education, majority of the respondents have gone up to primary level of education (46.66 per cent). 30 per cent of the respondents were illiterate.

The study shows that 68.33 per cent of the respondents have low level of income. 25.00 per cent have a medium level of annual income and a considerable small percentage of 6.66 have got a high level of income.

Majority of the respondents lived in nuclear family system, which makes a percentage of 90.83 and the remaining 9.16 per cent lived in joint family system. 


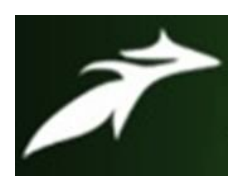

ARAVIND V. RAMA DAS et al, International Journal of Advances in Agricultural Science and Technology, Vol.8 Issue.7, July-2021, pg. 116-122

ISSN: 2348-1358

Impact Factor: 6.057

NAAS Rating: 3.77

The distribution of respondents according to mass media exposure reveals that, 36.66 per cent of the respondents have got a high level of exposure to mass media, followed by 35.00 per cent having a low level of exposure. 28.33 per cent of the respondents have a medium level of mass media exposure.

In terms of extension contact, 59.16 per cent of the respondents maintained a medium level of extension contact. 30.83 per cent had a low level of contact, whereas a percentage of 10.00 maintained high level of extension contact.

The study depicts that 80.83 per cent of the respondents maintained a high level of progressiveness, followed by 14.16 per cent having medium level and a small percentage of 5.00 with a low level of progressiveness.

Majority of the respondents, 64.16 per cent has got a high level of scientific orientation, followed by 26.66 per cent having a medium level and a small percentage of 9.16 with a low level of scientific orientation.

Table 2: Factors influencing tribal farmers to shift from traditional to modern agricultural practices

[Agree (A), Undecided (UD), Disagree (DA), Frequency (F), Percentage (P \% ).]

\begin{tabular}{|c|c|c|c|c|}
\hline \multirow[t]{2}{*}{ Sl.no. } & \multirow[t]{2}{*}{ Factors influencing } & \multicolumn{3}{|c|}{ Response of the respondents } \\
\hline & & A. $\mathbf{F}(\%)$ & UD. $F(\%)$ & DA. F(\%) \\
\hline 1 & Interaction with progressive farmers & $102(85.00)$ & $14(11.66)$ & $4(3.33)$ \\
\hline 2 & Influence of Television & $88(73.33)$ & $2(1.66)$ & $30(25.00)$ \\
\hline 3 & Influence of Radio & $5(4.16)$ & $13(10.83)$ & $102(85.00)$ \\
\hline 4 & Influence of Newspaper & $12(10.00)$ & $13(10.83)$ & $95(79.16)$ \\
\hline 5 & Influence of Internet & $19(15.83)$ & $2(1.66)$ & $99(82.50)$ \\
\hline 6 & Group discussions/Meetings & $40(33.33)$ & $0(0.00)$ & $80(66.66)$ \\
\hline 7 & Training programmes & $46(38.33)$ & $0(0.00)$ & $74(61.66)$ \\
\hline 8 & Result demonstration & $0(0.00)$ & $0(0.00)$ & $120(100.00)$ \\
\hline 9 & Method demonstration & $0(0.00)$ & $0(0.00)$ & $120(100.00)$ \\
\hline 10 & Field visit & $0(0.00)$ & $0(0.00)$ & $120(100.00)$ \\
\hline 11 & Exhibition & $0(0.00)$ & $0(0.00)$ & $120(100.00)$ \\
\hline 12 & Change in family type & $115(95.83)$ & $3(2.50)$ & $2(1.66)$ \\
\hline
\end{tabular}




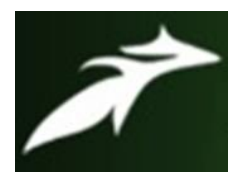

ARAVIND V. RAMA DAS et al, International Journal of Advances in Agricultural Science and Technology, Vol.8 Issue.7, July-2021, pg. 116-122

ISSN: 2348-1358

Impact Factor: 6.057

NAAS Rating: 3.77

\begin{tabular}{|c|c|c|c|c|}
\hline 13 & $\begin{array}{l}\text { Lack of interest of family labour in traditional } \\
\text { farming system }\end{array}$ & $82(68.33)$ & $35(29.16)$ & $3(2.50)$ \\
\hline 14 & $\begin{array}{l}\text { Lack of interest of younger generation in } \\
\text { traditional farming }\end{array}$ & 107(89.16) & $9(7.50)$ & $4(3.33)$ \\
\hline 15 & More yield in modern farming & $86(71.66)$ & $8(6.66)$ & $26(21.66)$ \\
\hline 16 & More income from modern farming & $85(70.83)$ & $10(8.33)$ & $25(20.83)$ \\
\hline 17 & Less time in modern farming & $81(67.50)$ & $19(15.83)$ & $20(16.66)$ \\
\hline 18 & $\begin{array}{l}\text { Reduced work burden in modern methods of } \\
\text { farming }\end{array}$ & $100(83.33)$ & $18(15.00)$ & $2(1.66)$ \\
\hline 19 & Progressiveness & $79(65.83)$ & $39(32.50)$ & $2(1.66)$ \\
\hline 20 & Land holding & 113(94.16) & $4(3.33)$ & $3(2.50)$ \\
\hline 21 & Education & $103(85.83)$ & 14(11.66) & $3(2.50)$ \\
\hline 22 & Status in society & $43(35.83)$ & $28(23.33)$ & $49(40.83)$ \\
\hline 23 & Immediate results in modern farming & $87(72.50)$ & $11(9.16)$ & $22(18.33)$ \\
\hline
\end{tabular}

Table 3: Overall of the factors influencing respondents to shift from traditional to modern agricultural system

\begin{tabular}{|l|l|l|l|}
\hline Sl. No & $\begin{array}{l}\text { Scientific } \\
\text { orientation }\end{array}$ & Frequency & Percentage \\
\hline 1 & Low (23-46) & 19 & 15.83 \\
\hline 2 & Medium (47-50) & 53 & 44.16 \\
\hline 3 & High (50 above) & 48 & 40.00 \\
\hline & Total & 120 & 100.00 \\
\hline
\end{tabular}

From the table-3, the results can be depicted as follows.

The data from the table reveals that majority of the respondents, 44.16 per cent, belong to medium level, i.e. they have been influenced at a medium level by the factors to shift towards modern farming. 40.00 per cent of 


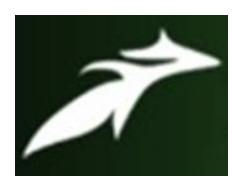

ARAVIND V. RAMA DAS et al, International Journal of Advances in Agricultural Science and Technology,

Vol.8 Issue.7, July-2021, pg. 116-122

ISSN: 2348-1358

Impact Factor: 6.057

NAAS Rating: 3.77

the respondents belong to high level, as they are highly influenced by the factors and a percentage of 15.83 belong to low level, being influenced slightly by the factors.

Table 4: Association between Independent Variables and Factors Influencing. $\mathbf{n}=120$.

\begin{tabular}{|l|l|l|}
\hline Sl.no. & Characteristics & 'r' value \\
\hline 1. & Age & $-0.433^{* *}$ \\
\hline 2. & Education & $0.372^{* *}$ \\
\hline 3. & Annual Income & 0.023 \\
\hline 4. & Family type & $-0.349^{* *}$ \\
\hline 5. & Mass Media Exposure & $0.398^{* *}$ \\
\hline 6. & Extension contact & $0.209^{*}$ \\
\hline 7. & Progressiveness & $0.320^{* *}$ \\
\hline 8. & Scientific orientation & 0.164 \\
\hline
\end{tabular}

** Correlation is significant at the 0.01 level (2-tailed).

* Correlation is significant at the 0.05 level (2-tailed).

The above Table-4 indicates the association between independent variables and the factors influencing tribal farmers to shift from traditional to modern farming system by using Karl Pearson's Co-efficient of Correlation. The results clearly depict that the selected characteristics of farmers such as Education, Mass Media Exposure and Progressiveness have a positive and highly significant relationship at 0.01 level of probability with factors influencing the respondents. Extension contact has a positive and significant relationship with factors, whereas Age and Family type has negative and highly significant relationship. Annual income and scientific orientation do not have a relationship with the factors influencing the respondents.

\section{Conclusion}

It was concluded that though the tribal farmers are among the important custodians of traditional knowledge in the Country, several factors have impeded them from practicing the same. The analysis and comparison of the collected data has shown that there is a positive and highly significant relationship between Education, Mass Media and Progressiveness with factors influencing. The Kurichiya tribal farmers have started to move away from the traditional methods towards the adoption of modern farming. Though they have started the adoption of modern farming, they have not completely adopted the modern methods. The agricultural practices followed by the tribal farmers can be claimed to be lying somewhere between the traditional and the modern farming methods. 


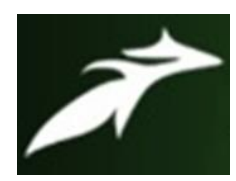

ARAVIND V. RAMA DAS et al, International Journal of Advances in Agricultural Science and Technology,

Vol.8 Issue.7, July-2021, pg. 116-122

ISSN: 2348-1358

Impact Factor: 6.057

NAAS Rating: 3.77

\section{References}

[1]. Jalaja, V. and Kala, P.A. (2015). Case study of tribal farmers agricultural information needs and accessibility in Attapady tribal block, Palakkad. IOSR Journal of Humanities and Social Science, 20(8), pp. 07-12.

[2]. Anooja, C. (2017). Agricultural mobility of Tribes: A Village level study in Kerala. Munich Personal RePEc Archive, MPRA Paper No. 85135.

[3]. Sanal, V.R. and Atheeque, M.P.P. (2018). Socio cultural and agricultural practices of kurichiyan tribe in Wayanad: A historical analysis. International Journal of Advanced Scientific Research, 3(2), pp. 51-58.

[4]. David et al, (2012). Role of Indigenous Knowledge in Traditional Farming System on Natural Resource Management. Conference paper.

[5]. Vaisakh B and Sood, S. (2017). Tribal settlement in Wayanad, Kerala. International Journal of Civil Engineering and Technology, 8(5), pp. 1316-1327.

[6]. Syam S.K., (2016). Kurichiya Tribe of Kerala - A Phonological Study. Language in India, 16(1), pp. 296-306.

[7]. Kaumar, D., and Srinath, P. (2011). Climate Trends in Wayanad: Voices from the Community. UGC sponsored National Seminar on Recent Trends in Climate and Impact of Climate Change on South-West India.

[8]. Borthakur, A. and Singh, P. (2012). Agricultural Research in India: An Exploratory Study. International Journal of Social Science and Interdisciplinary Research, 1(9), pp. 59-74. 